\title{
PEMBENTUKAN POSKESTREN DI PESANTREN TAHFIZD NURANI INSANI DESA BALECATUR GAMPING SLEMAN, YOGYAKARTA
}

\author{
Kustiningsih $^{1^{*}}$, Diyah Candra Anita $\mathrm{K}^{2}$, Royan Utsani ${ }^{3}$ \\ 1,2Program Studi Ilmu Keperawatan, Fakultas Ilmu Kesehatan, Universitas \\ 'Aisyiyah Yogyakarta \\ ${ }^{3}$ Lembaga Pendidikan dan Pengembangan Islam, Universitas 'Aisyiyah \\ Yogyakarta
}

*kustiningsih@unisayogya.ac.id

\begin{abstract}
ABSTRAK
Kegiatan Pengabdian Masyarakat pembentukan POSKESTREN telah dilaksanakan di Pesantren Tahfizd NURANI INSANI Desa Balecatur Gamping Sleman Yogyakarta. Tujuan dari kegiatan ini adalah untuk memberikan sosialisasi pembentukan POSKESTREN dan layanan kesehatan untuk warga pesantren dengan melibatkan civitas akademika Program Studi Ilmu Keperawatan, Fakultas Ilmu Kesehatan Universitas Aisyiyah Yogyakarta dan Kemenristek Dikti dengan Pengelola Pondok Pesantren. Kegiatan dilaksanakan dengan memberikan transfer informasi dan pelatihan santri husada mengenai konsep kesehatan, melatih skill pemeriksaan kesehatan meliputi pemeriksaan tekanan darah, gula darah, asam urat, kolesterol, $\mathrm{Hb}$, balut bidai, penatalaksanaan kegawatdaruratan dan simulasi layanan kesehatan. Pelaksanaan kegiatan dimulai dengan melakukan koordinasi antara pengurus Pesantren dan Puskesmas Gamping I yang menaungi, pemilihan calon kader kesehatan Santri Husada, Pelatihan kader santri Husada, survey mawas diri, penyediaan sarana dan prasarana fasilitas layanan kesehatan dan layanan jasa kesehatan POSKESTREN. Hasil dari kegiatan ini adalah telah terbentuknya kader kesehatan Santri Husada Putra dan Putri yang terlatih sejumlah 25 orang, tersusunnya modul pelatihan kesehatan Santri Husada, tersusunnya leaflet/ poster kesehatan pendukung layanan kesehatan, tersedianya fasilitas POSKESTREN seperti, ruang dan alat-alat pemeriksaan serta pemberian jasa layanan kesehatan untuk santri dan warga masyarakaat yang buka per hari 2 jam. Kerjasama yang baik antara akademisi, pengelola pesantren serta petugas kesehatan dari Puskesmas dapat meningkatkan kualitas kesehatan lebih baik. Pembinaan kesehatan terhadap Santri Husada dan POSKESTREN perlu dilaksanakan secara kontinyu guna meningkatkan derajat kesehatan warga pesantren secara keseluruhan.
\end{abstract}

Kata kunci: pondok pesantren; poskestren; hygiene, sanitasi lingkungan

\begin{abstract}
Community Service: POSKESTREN (Health Services for Pesantren residance) have been carried out at the Pesantren Tahfizd NURANI INSANI Balecatur Gamping, Sleman, Yogyakarta. The purpose of this activity are to provide information on the formation of POSKESTREN and health services for pesantren residents by involving the academic community of Nursing Studies Program, Faculty of Health Sciences, Yogyakarta Aisyiyah University and Ministry of Research, Technology and Higher Education, Republic of Indonesia and cooperation with Management of Islamic Boarding Schools. The activity was carried out by providing health education and training of Santri Husada, training of health examination skills including checking blood pressure, blood sugar, uric acid, cholesterol, hemoglobin, splint dressing, emergency management and health service simulation. The activity begins with coordinating between the boarding school administrators and Primary health care of Gamping I who overshadow, the selection of prospective Santri Husada health cadres, the training of Santri Husada cadres, self-surveillance survey, provision of facilities and infrastructure of health service facilities and POSKESTREN health services. The results of this activity are the formation of Santri Husada health cadres trained by 25 people, the compilation of Santri Husada health training modules, the compilation of leaflets/ posters of health services, facility at POSKESTREN health service are axamination room for santri and public community and open 2 hours per day. Good cooperation between academics, santri and pesantren managers and health workers from the primary health carecan improve the quality of health. Health development for Santri Husada and POSKESTREN needs to be implemented to improve the overall health status of pesantren residents.
\end{abstract}

Keywords: pondok pesantren; poskestren; hygiene, environmental sanitation 


\section{PENDAHULUAN}

Data di Pusat Pengembangan Penelitian dan Pendidikan Pelatihan Kementrian Agama (2011) menunjukkan bahwa jumlah santri pondok pesantren di 33 provinsi di Indonesia mencapai 3,66 juta jiwa yang tersebar di 25.000 pondok pesantren. Jumlah pesantren di Yogyakarta, berdasarkan data Bagian Perencanaan dan Data Setditjen Pendidikan Islam Departemen Agama R.I (2009) didapatkan jumlah santri 27.967 dengan jumlah pondok pesantren sebanyak 294. Jumlah pondok pesantren ini tersebar meliputi wilayah Kota Yogyakarta $(7,1 \%)$ dengan 3.333 jumlah santri, Gunungkidul (11,9\%) dengan 2.144 santri, Kulon Progo (15,3\%) dengan 6.401 santri, Bantul $(26,5 \%)$ dengan 11.468 santri, dan Sleman $(39,1 \%)$ dengan 4.621 santri.

Jenis pesantren yang ada di Yogyakarta sebagian besar mengharuskan santri untuk tinggal dan menetap sementara waktu di lingkungan asrama pesantren dalam periode masa belajar. Banyaknya jumlah santri yang tinggal bersama di pesantren dengan bermacam latar belakang ini, memungkinkan munculnya banyak permasalahan kesehatan.

Hasil penelitian Herryanto (2004)

dalam Budisuari \& Pranata (2016) menunjukkan bahwa pondok pesantren masih rawan dalam hal hygiene dan sanitasi lingkungan. Hal ini terlihat dalam hal pengelolaan sampah yang belum benar, kualitas air bersih belum memadai, PHBS (Perilaku Hidup Bersih dan Sehat) yang belum maksimal di lingkungan Pesantren, serta minimnya informasi dan akses kesehatan. Berdasarkan Profil Kesehatan Indonesia tahun 2011, penyakit kulit masih berada di peringkat ketiga dengan jumlah 247.179 kasus.

Penelitian Julia (2013) dan Akmal et al. (2013) menemukan bahwa asrama Pondok Pesantren juga merupakan tempat yang rentan dalam penyebaran penyakit kulit. Scabies (penyakit kulit) seolah-olah menjadi penyakit rutin yang harus diderita oleh santri. Bahkan ada sebagian budaya masyarakat yang salah tentang penyakit kulit ini, dimana seorang santri belum dikatakan sebagai santri sebenarnya jika belum pernah terkena penyakit kulit selama belajar di
Pondok Pesantren (Anonim, 2017; Wijayanti, 2007).

Permasalahan kesehatan yang sama terjadi juga di Pondok Pesantren Tahfiz Qur'an Yatim Nurani Insani Putra di dusun Sumber Gamol dan Pesantren Putri di dusun Sumber Desa Balecatur Kecamatan Gamping. Gamping adalah salah satu kecamatan di Kabupaten Sleman yang terbagi dalam 5 kelurahan, 59 dusun, 187 Rukun Warga (RW), dan 529 Rukun Tetangga (RT), dengan luas wilayah kurang lebih 2683 Ha (Efendy \& Makhfudli, 2009).

Pesantren ini merupakan jenis pesantren modern yang menerapkan sistem sekolah umum pada pagi hari dan sore sampai malam hari berfokus pada pembelajaran hafalan Al Qur'an di pesantren. Hasil observasi dan wawancara dengan Ustadz serta pengelola Pondok Pesantren didapatkan bahwa santri didik yang tinggal di pesantren berjumlah 150 anak, rentang usia 9-20 tahun dengan pendidikan tingkat SD, SLTP, SLTA atau SMK (Sekolah Menengah Kejuruan) serta Perguruan Tinggi.

Masalah kesehatan yang ada pada Pondok Pesantren Tahfiz Qur'an Yatim Nurani Insani diantaranya $12,87 \%$ santri pernah mengalami penyakit kulit (scabies), cacar air, konjungtivitis yang rentan menyebar ke sesama santri dan penyakit asma $(1,17 \%)$ dengan angka kekambuhan 1-2 bulan sekali. Data lain didapatkan 53 santri di Pesantren pernah mengalami keracunan masal akibat olahan ikan tongkol yang dimasak oleh juru masak Pesantren, sehingga menyebabkan para santri harus dilakukan perawatan di RS PKU Muhammadiyah Gamping pada bulan Februari 2016 yang lalu. 

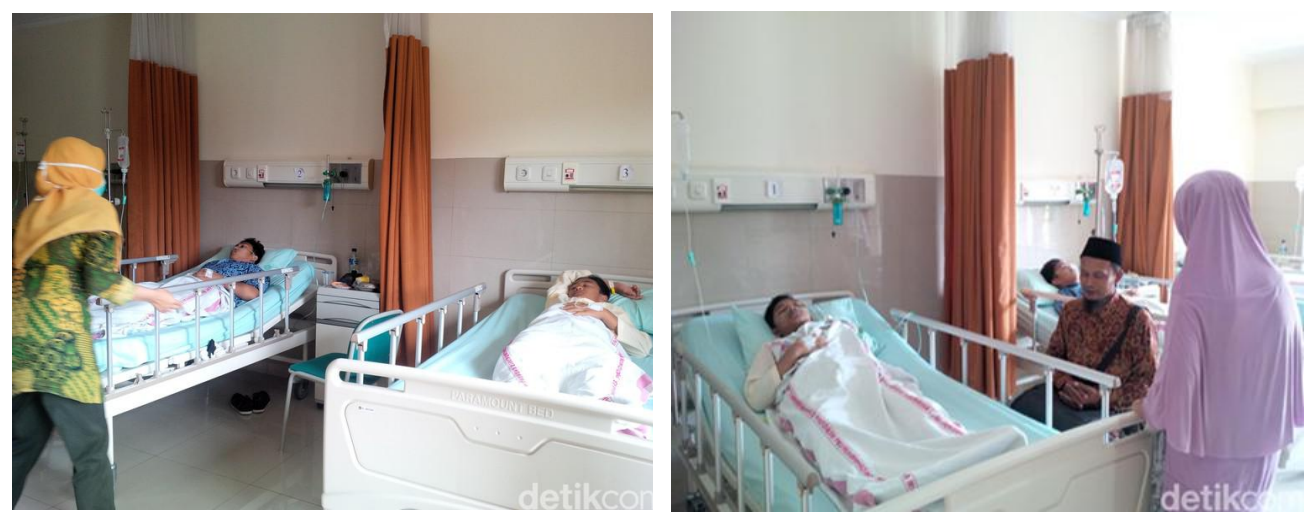

Gambar 1. Santri Pondok Pesantren Nurani Insani masuk rumah sakit saat keracunan ikan tongkol

Dengan jumlah santri yang cukup banyak, permasalahan lain yang sering dikeluhkan adalah masalah kebersihan dan PHBS warga pesantren yang belum secara optimal dilaksanakan. Misalnya budaya mencuci tangan, membuang sampah, dan kebersihan di area Pesantren. Pesantren Nurani Insani juga belum mempunyai unit kesehatan khusus dalam menangani kesehatan santri dan warga pesantren seperti pengadaan dan pengelolaan obat $\mathrm{P} 3 \mathrm{~K}$, pendataan dan pemeriksaan kesehatan rutin untuk santri. Stuktur organisasi di Pesantren yang membawahi bidang kesehatan masih belum ada serta minimnya pembinaan kesehatan intensif oleh petugas kesehatan.

Pondok pesantren sebagai wadah penyelenggara pendidikan telah terbukti mampu menjadi penggerak masyarakat di bidang pendidikan, sosial budaya dan ekonomi, tetapi tidak di bidang kesehatan. Pemerintah telah memberikan perhatian besar tentang masalah kesehatan di lingkungan Pesantren ini, melalui Peraturan Menteri Kesehatan RI No 1 tahun 2013. Idealnya setiap Pondok Pesantren mempunyai unit kesehatan atau Pos Kesehatan Pesantren (POSKESTREN) sebagai wujud pemberdayaan masyarakat (UKBM) bidang kesehatan di lingkungan Pesantren. Akan tetapi program ini belum terlaksana secara merata dan optimal, salah satunya Pesantren Putra dan Putri Tahfiz Qur'an Yatim Nurani Insani ini yang belum tersentuh oleh program ini. Oleh karena itu, penulis merasa tertarik melaksanakan program pengabdian masyarakat dengan membentuk dan mengaktifkan Pos
Kesehatan Pesantren (POSKESTREN) yang bertujuan meningkatkan pengetahuan kesehatan dan sikap hidup sehat serta pemberian layanan kesehatan untuk warga Pesantren.

\section{METODE}

Metode yang dilakukan dalam merealisasikan program pengabdian masyarakat berupa pembentukan POSKESTREN ini adalah:

a. Metode advokasi dan koordinasi. Kegiatan ini bertujuan untuk mendapatkan dukungan dari penentu kebijakan Ketua dan pengelola Pondok Pesantren terhadap kelancaran dan keberlangsungan pembentukan dan pelaksanaan Pos Kesehatan Pesantren (POSKESTREN).

b. Metode promosi dan sosialisasi Pos Kesehatan Pesantren (POSKESTREN) yang telah terbentuk. Kegiatan ini bertujuan untuk memperkenalkan keberadaan Pos Kesehatan Pesantren (POSKESTREN) kepada semua warga Pesantren dan masyarakat sekitar serta pihak yang terkait dalam rangka memperluas akses dan pengembangan dukungan serta jaringan.

c. Metode pemberdayaan sumber daya manusia yaitu pengelola dan pengurus Pos Kesehatan Pesantren (POSKESTREN). Kegiatan ini bertujuan untuk menyiapkan dan memberdayakan SDM (Pengelola, Pengurus dan Kader Kesehatan (Santri Husada). 
d. Metode penyediaan sumber dana terhadap program pembentukan dan pelaksanan Pos Kesehatan Pesantren (POSKESTREN). Kegiatan ini bertujuan untuk mendukung biaya operasional POSKESTREN secara rutin melalui pengembangan kegiatan ekonomi produktif, penggalangan dana baik yang bersumber dari Pesantren atau pihak eksternal/sponsor.

e. Metode pelatihan kader kesehatan (santri husada) siap guna. Metode ini bertujuan untuk menyiapkan kader kesehatan yang baik dan berkualitas dalam memberikan pelayanan kesehatan di Pos Kesehatan Pesantren (POSKESTREN) dan mampu memotivasi warga Pesantren agar sadar kesehatan dan sadar lingkungan sehat.

f. Metode survei mawas diri. Metode ini bertujuan untuk melakukan screening masalah kesehatan secara umum di lingkungan Pondok Pesantren sehingga ada inventarisasi data dan informasi kesehatan meliputi masalah kesehatan lingkungan, PHBS, Gizi, sarana dan prasarana di Pesantren.

g. Metode penyediaan sarana prasarana/fasilitas kesehatan. Sarana prasarana merupakan hal pendukung utama suksesnya program ini. Sarana prasarana tersebut antara lain fasilitas ruangan layanan kesehatan POSKESTREN yang representatif, alat-alat untuk pemeriksaan kesehatan, dan kotak P3K.

h. Metode pelaksanaan jasa layanan kesehatan. Pelaksanaan jasa layanan kesehatan dilakukan secara bergantian oleh kader-kader kesehatan yang sudah terlatih sesuai jadwal yang dibentuk. Layanan Poskestren buka setiap hari minimal 2 jam untuk santri atau warga Pesantren yang sakit atau memerlukan pemeriksaan kesehatan, pemeriksaan kesehatan rutin untuk santri dilakukan tiap satu bulan sekali, ada program Jum'at bersih, ada lomba kamar bersih, penyuluhan kesehatan dilakukan rutin pada warga Pesantren tiap 1 bulan sekali. i. Metode Monitoring dan Evaluasi. Pelaksanaan kegiatan akan dilakukan monitoring dan evaluasi oleh pengelola program. Monitoring dan evaluasi digunakan untuk mendeteksi adanya hambatan pada pelaksanaan program. Harapannya hasilnya dapat digunakan untuk perbaikan pada pelaksanaan program berikutnya.

j. Metode Pencatatan dan Pelaporan. Pencatatan dan pelaporan kegiatan dilakukan oleh pelaksana kegiatan dan pengurus. Hasil pencatatan dan pelaporan tersebut dapat dijadikan data kesehatan warga Pesantren yang dapat digunakan untuk perbaikan dan pengembangan program.

\section{HASIL DAN PEMBAHASAN}

Implementasi kegiatan PKM Pembentukan Poskestren ini, dimulai dari bulan Mei 2019 dan terus berlangsung sampai sekarang. Adapun langkahlangkah yang dilaksanakan dalam pembentukan Poskestren ini adalah:

\section{a. Koordinasi}

Koordinasi dilaksanakan sejak bulan Mei 2019 dengan Pimpinan Pesantren dan Pelaksana harian Pesantren. Fokus koordinasi adalah penyampaian maksud dan tujuan pendirian poskestren di wilayah pesantren. Hasil kesepakatan dari pengusul dan pimpinan Pesantren adalah dikeluarkannya SK Pendirian Poskestren oleh Pesantren Nurani dan kesepakatan dilakukannya kegiatan sejak bulan Juli 2019.

Koordinasi selanjutnya dilakukan ke Puskesmas Gamping I yang merupakan fasilitas kesehatan yang berada di wilayah kerja kecamatan pada bulan akhir Juli 2019. Program Poskestren sendiri di wilayah kerja Puskesmas Gamping I belum pernah ada, sehingga rencana pembentukan Poskestren ini yang pertama kali dilakukan di wilayah Gamping dan disambut baik oleh Kepala Puskesmas Gamping I. 


\section{b. Sosialisasi Program POSKESTREN}

Sosialisasi Poskestren adalah langkah awal pengenalan program Pos Kesehatan Pesantren kepada seluruh warga pesantren. Kegiatan ini dilaksanakan pada tanggal 1 Agustus 2019, jam 20.00-22.30 WIB, dengan dihadiri sekitar 75 orang warga pesantren. Peserta sosialisasi ini meliputi santri putra dan putri, ustadz, ustadzah, pengurus dan pengelola pesantren yang telah diberikan undangan sebelumnya. Materi yang disampaikan saat sosialisasi meliputi: pengertian Poskestren, tujuan, manfaat, sasaran poskestren, pelaksana poskestren, alasan pendirian poskestren, dan sistem kerja poskestren. Setelah penjelasan diberikan sesi tanya jawab seputar pembentukan poskestren dan kesehatan. Antusiasme warga pesantren terhadap kegiatan ini baik, ditunjukkan dengan banyaknya pertanyaan yang didiskusikan.

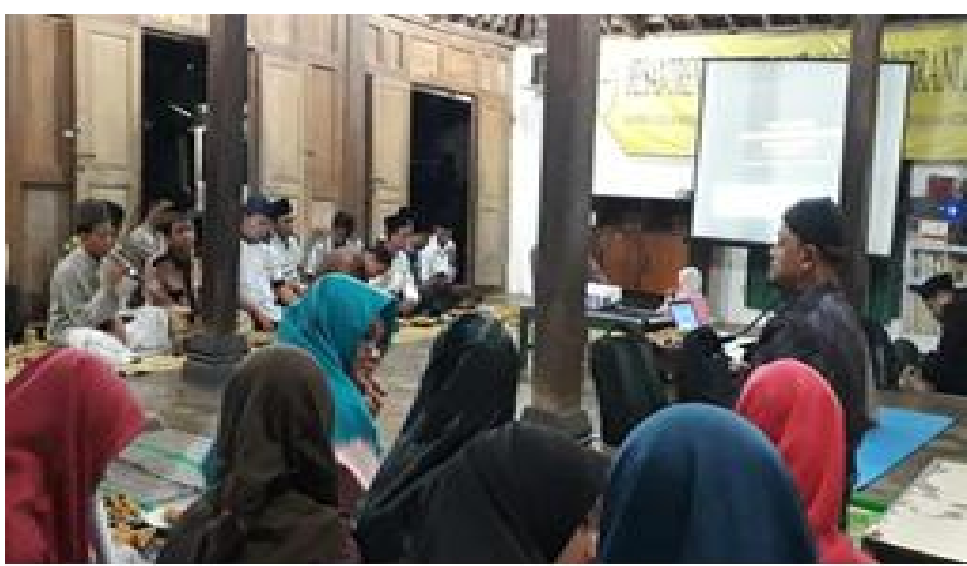

Gambar 2. Sosialisasi program POSKESTREN

\section{c. Pemilihan kader kesehatan (Santri Husada)}

Hasil perekrutan kader kesehatan/ santri husada:

Tabel 1. Karakteristik Kader Santri Husada

\begin{tabular}{ccc}
\hline \multirow{2}{*}{ Karakteristik } & Frekuensi & Persentasi \\
\cline { 2 - 3 } Jenis kelamin: & $\mathbf{( f )}$ & $\mathbf{( \% )}$ \\
\hline Laki-laki & 11 & 44 \\
\hline Perempuan & 14 & 56 \\
\hline Usia: & & 80 \\
\hline$<20$ tahun & 20 & 20 \\
\hline Tingkat Pendidikan: & 5 & 0 \\
\hline SMP & & 92 \\
\hline SMU/K & 0 & 8 \\
\hline PT & 23 & 88 \\
\hline Pengalaman Organisasi: & 2 & 12 \\
\hline Organisasi & 22 &
\end{tabular}


Kader santri husada yang terpilih ada 25 santri, yang terdiri dari 11 santri laki-laki dan 14 santri perempuan, dengan mayoritas usia dibawah 20 tahun dan pendidikan mayoritas SMU atau sederajat dan pernah mengikuti organisasi sebelumnya.

\section{d. Pelatihan Kader Santri Husada}

Pelatihan kader santri husada dilakukan bertahap dalam 4 sesi pelatihan. Pelatihan pertama dilaksanakan pada tanggal 10 Agustus 2019. Dalam pelatihan pertama ini materi yang disampaikan adalah konsep kesehatan dalam Islam dan aplikasinya dalam pesantren yang meliputi: sehat dalam perspektif Islam, pola hidup sehat rasul, hikmah makanan halal, melaksanakan 5 perkara sebelum 5 perkara, aplikasi hidup sehat.

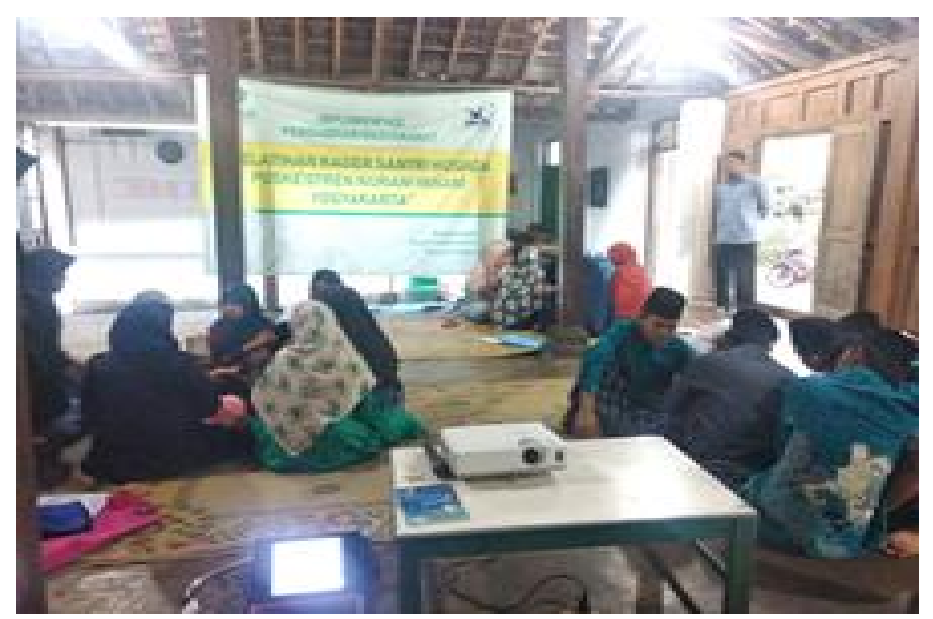

Gambar 3. Pelatihan Santri Husada

Selain itu santri juga dilatih suhu tubuh, nadi, respirasi dan melakukan pemeriksaan kesehatan berupa pengukuran tekanan darah serta kesehatan tanda-tanda vital meliputi: pengukuran gigi.
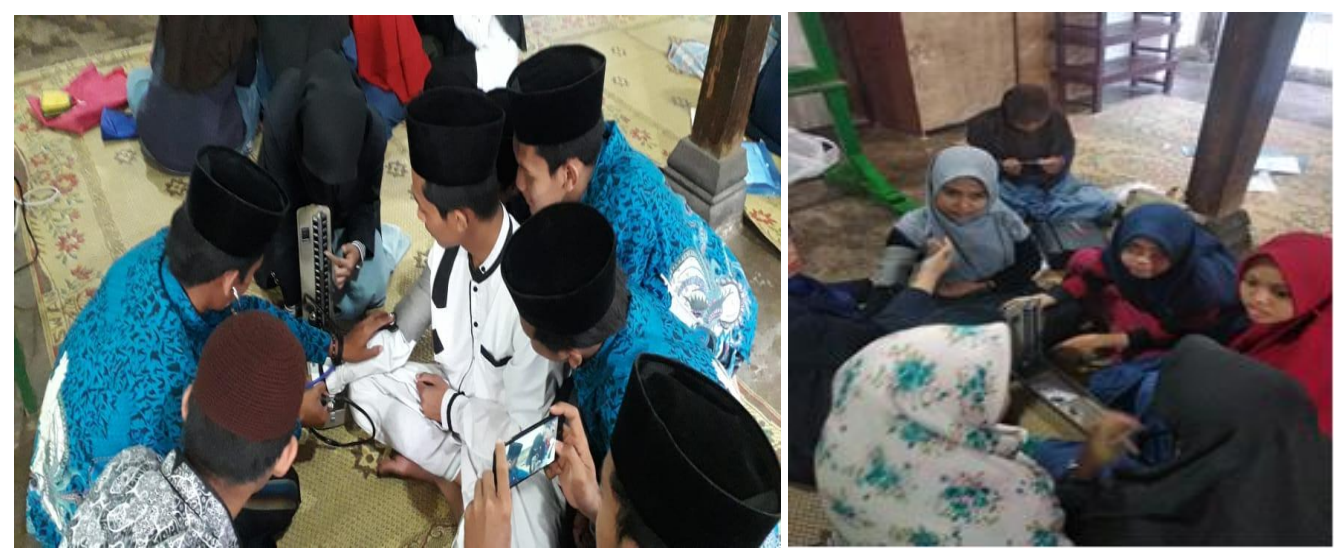

Gambar 4. Pelatihan Pengukuran Tanda Vital (Suhu, Nadi, Respirasi, Tensi)

Pelatihan tahap kedua dilakukan tanggal 18 Agustus 2019. Pada pelatihan ini disampaikan materi tentang kesehatan reproduksi, PHBS, pengelolaan sampah dan praktek pemeriksaan darah meliputi: pemeriksaan gula darah, kolesterol, asam urat, dan $\mathrm{Hb}$. 


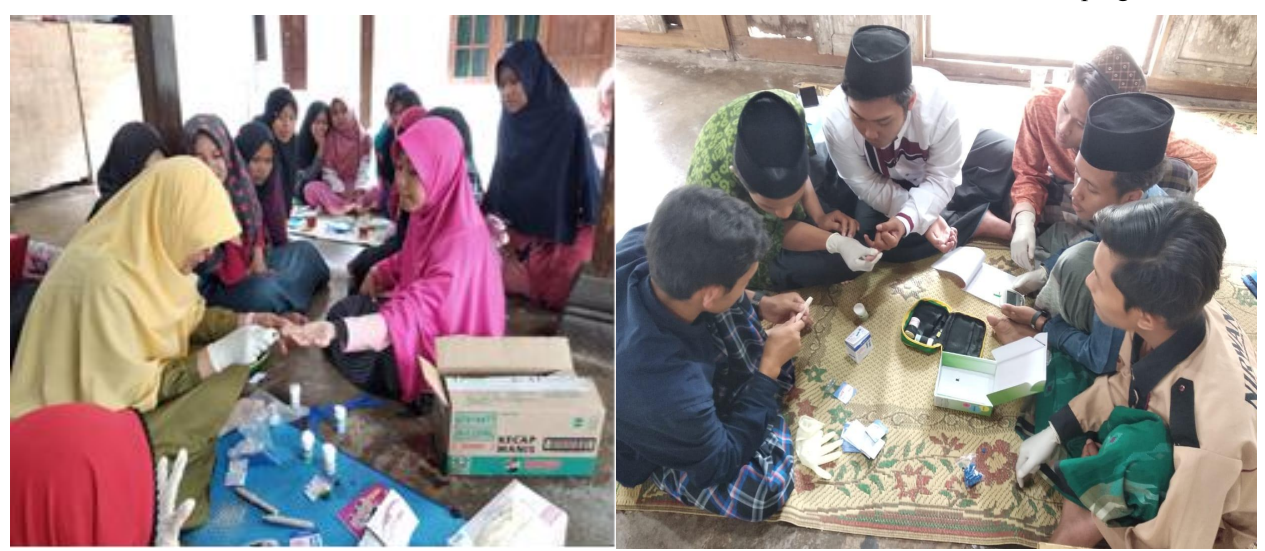

Gambar 5. Pelatihan pemeriksaan gula darah, asam urat, kolesterol \& $\mathrm{Hb}$

Pelatihan tahap ke tiga penatalaksanaan fraktur, tersedak, dilaksanakan tanggal 25 Agustus 2019. penanganan pingsan, penanganan luka Pada tahap ke tiga pelatihan, Santri (gores, tertusuk, luka bakar) dan evakuasi Husada dibekali tentang penatalaksanaan korban. kegawat daruratan, latihan balut dan bidai,

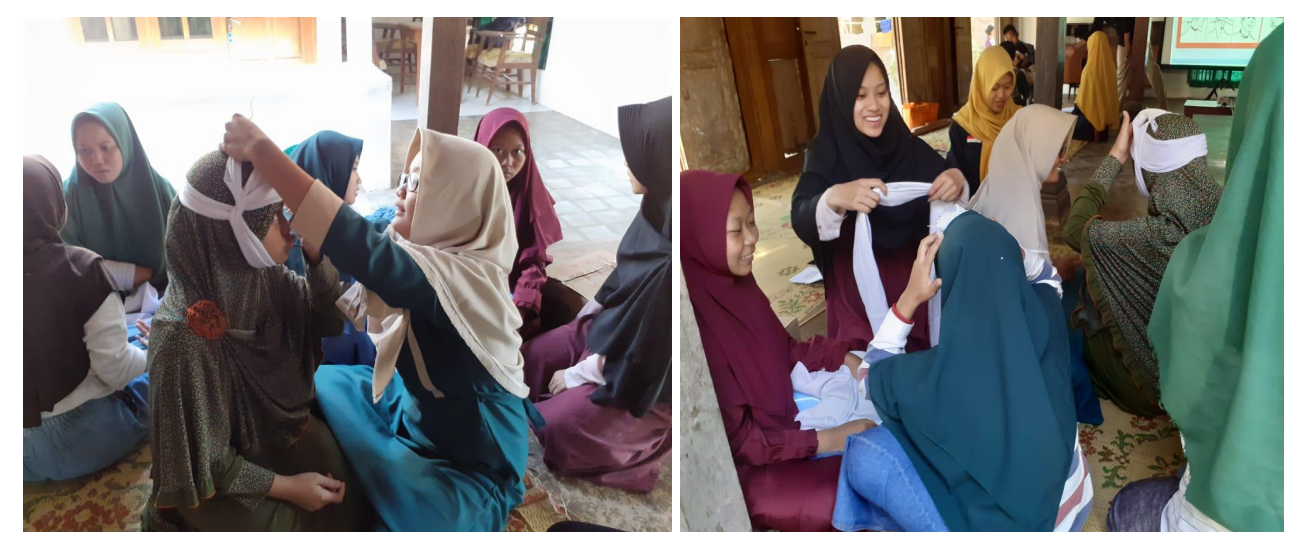

Gambar 6. Pelatihan balut bidai

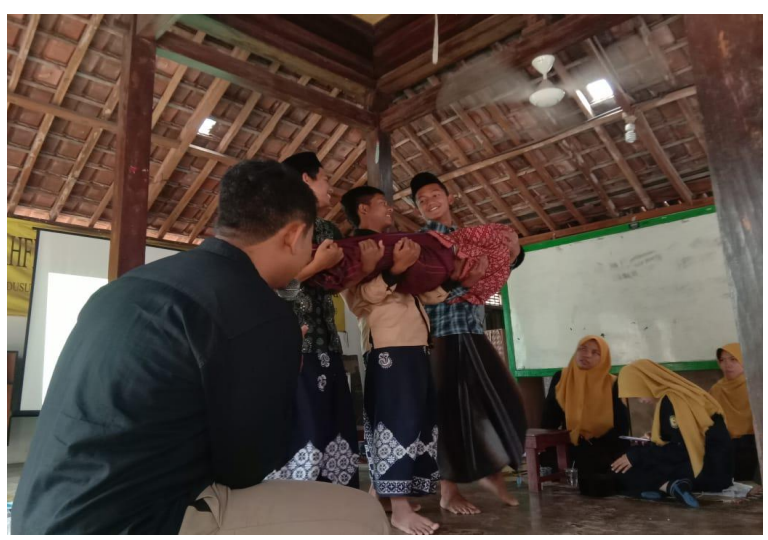

Gambar 7. Latihan evakuasi korban

Pelatihan tahap keempat obat-obatan dan P3K, survei mawas diri, dilaksanakan tanggal 31 Agustus 2019. alur pencatatan dan pelaporan serta Pada tahap keempat ini santri husada simulasi melakukan layanan kesehatan di diberikan pelatihan tentang pengelolaan Poskestren. 


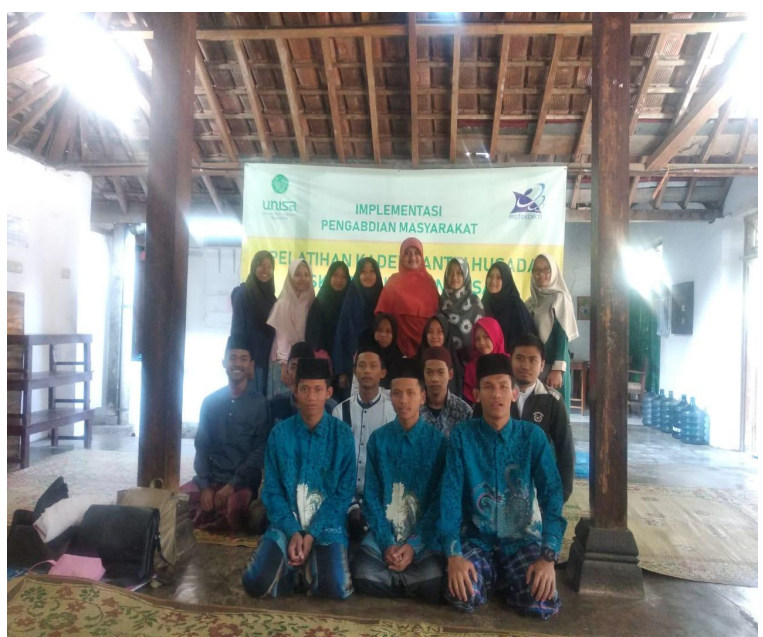

Gambar 8. Foto bersama usai pelatihan

\section{e. Survey Mawas Diri}

Pelaksanaan survei mawas diri dilaksanakan simultan oleh kader Santri Husada kepada seluruh santri dan warga pesantren dengan menganalisa dan menggali permasalahan kesehatan yang ada di lingkungan Pesantren. Permasalahan yang ada meliputi kebersihan lingkungan, perilaku hidup bersih dan sehat warga pesantren, dan screening kesehatan santri ustadz dan ustadzah.

Pelaksanaan program terencana
dengan melakukan kerja bakti di lingkungan pesantren dilaksanakan 6 September 2019. Sereening kesehatan santri dan warga pesantren dilaksanakan per 2 bulan. Pembiasaan perilaku hidup bersih dan sehat akan dilaksanakan oleh santri husada tiap pekan.

Hasil survey menunjukkan bahwa $65 \%$ santri belum memiliki sikap dan perilaku kesehatan yang baik, 30\% santri mengeluhkan sering mengalami gatalgatal, 13\% santri mengeluhkan mengenai kebersihan kamar mandi.

\section{f. Penyediaan Fasilitas Kesehatan Poskestren}

Poskestren Pesantren Nurani Insani terbagi menjadi 2 tempat layanan, yaitu di Gedung Pesantren Putra 1 lantai 2 dusun Sumber Gamol dan Gedung Pesantren Putri 3 lantai 1 dusun Sumber desa Balecatur Gamping Sleman
Yogyakarta. Fasilitas kesehatan untuk mendukung layanan kesehatan pada masing-masing Poskestren meliputi, meja periksa, tempat tidur pasien, alat kesehatan: stetoskop, tensi meter, termometer, GCU pemeriksaan gula darah, asam urat, $\mathrm{Hb}$, kolesterol, masker, sarung tangan, leaflet/poster kesehatan, obatobatan ringan dan kotak P3K.

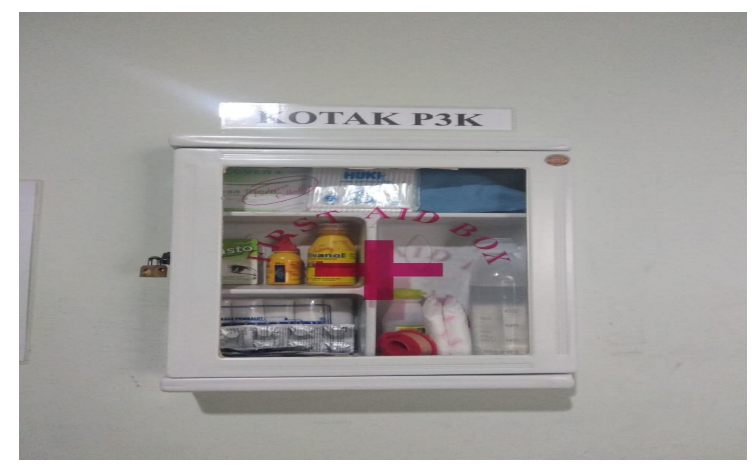

Gambar 9. Kotak P3K

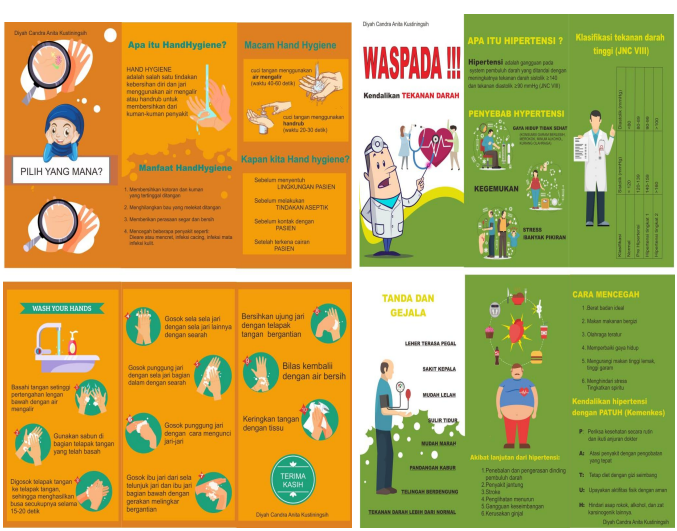

Gambar 10. Poster Kesehatan 

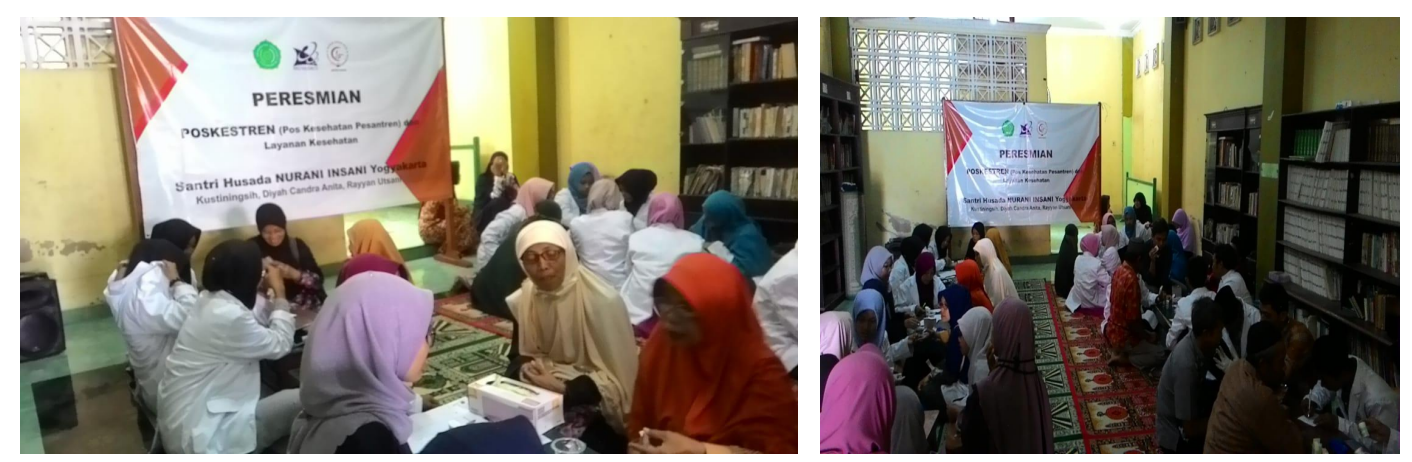

Gambar 13. Peresmian \& Layanan Kesehatan pada warga

\section{g. Pelaksanaan Jasa Layanan Kesehatan}

Jasa layanan kesehatan Poskestren dilaksanakan oleh santri husada pada hari aktif dengan alokasi waktu 2 jam per hari untuk santri dan warga pesantren. Layanan kesehatan untuk masyarakat umum dilaksanakan berbarengan dengan acara pengajian rutin Ahad Pertama tiap bulan. Pelaksanaan layanan untuk masyarakat dan jamaah umum dilaksanakan pada tanggal 1 September 2019 setelah acara pengajian berupa layanan pemeriksaan kesehatan, dan pemeriksaan kadar gula darah, asam urat, kolesterol, dan $\mathrm{Hb}$.

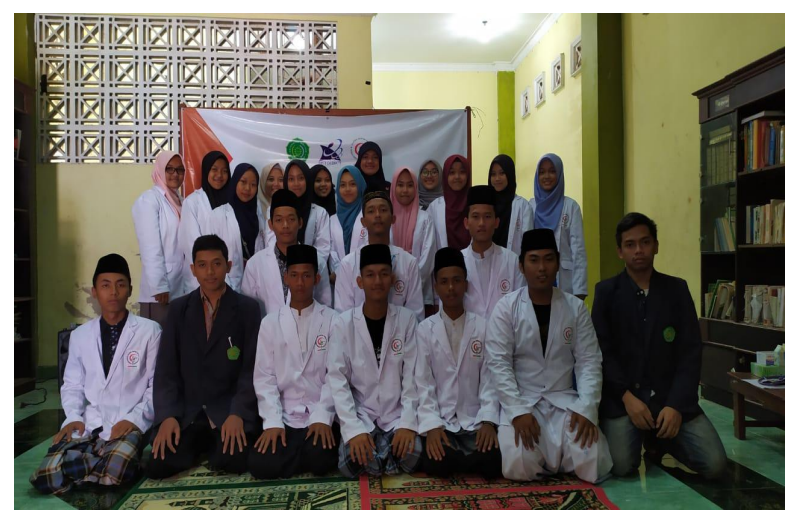

Gambar 11. Seragam Santri Husada

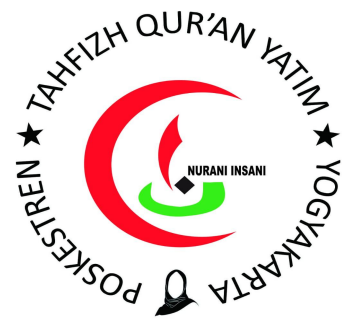

SANTRI HUSADA

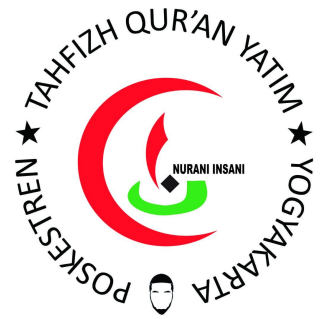

SANTRI HUSADA

Gambar 12. Logo Santri Husada Poskestren Putra \& Putri

\section{SIMPULAN}

Pelaksanaan program Pengabdian Masyarakat yang diselenggarakan oleh Program Studi Ilmu Keperawatan Fakultas Ilmu Kesehatan Universitas 'Aisyiyah Yogyakarta sudah terlaksana dengan baik, hal tersebut dapat dilihat dengan tercapainya:

1. Terbentuknya Kader kesehatan Santri Husada putra dan putri yang terlatih.

2. Tersusunnya modul pelatihan kesehatan santri husada. 
3. Tersusunnya leaflet/ poster kesehatan pendukung layanan kesehatan.

4. Tersedianya sarana dan prasarana fasilitas layanan kesehatan POSKESTREN di Pesantren Putra dan Putri

5. Layanan kesehatan untuk masyarakat umum bisa meningkatkan sumber pendapatan.

6. Kerjasama yang baik antara akademisi, santri dan pengelola pesantren serta petugas kesehatan dari Puskesmas meningkatkan kualitas kesehatan warga pesantren.

\section{DAFTAR PUSTAKA}

Akmal, SC., et al. (2013). Hubungan Personal Hygiene dengan KejadianSkabies di Pondok Pendidikan Islam Darul Ulum, Palarik Air Pacah, Kecamatan Koto Tangah Padang Tahun 2013. Jurnal Kesehatan Andalas. 2 (3): 164-167.

Anonim (2016). Manfaat Program POSKESTREN untuk Santri dan Santriwati. http://berita.baca.co.id/625673 9? origin $=$ relative $\&$ pageId $=2 \mathrm{e}$ 38577a-c265-4723-85c259b33baf1da3\&PageIndex $=1$ akses 13 Juni 2017.

Anonim, (2017). Daftar Desa dan Kelurahan di Kecamatan Gamping Kabupaten Sleman Yogyakarta.

http://www.nomor.net/ kodep os.php? i=desa-

kodepos\&sby $=000000 \&$ daera $\mathrm{h}=$ Kecamatan-Kab.-

Sleman\&jobs $=$ Gamping akses Juni 2017.

Budisuari, MA., Pranata, S. (2016). Up dating Islamic Boarding School Santri and Reproductive Health Information. Bulletin of
Health System Research. 19 (1): 64-73.

Departemen Agama RI. (2009). Daftar Jumlah Santri Dan Nama Kyai 2008/2009. http://pendis.kemenag.go.id/fi le/dokumen/santri-kyaipontren-81-82-91-92.pdf. Diakses tanggal 20 Mei 2018. Efendy, F., Makhfudli. (2009). Keperawatan Kesehatan Komunitas Teori dan Praktek dalam Keperawatan. Tujuan POSKESTREN. https://books.google.co.id/boo ks?id=LKpz4vwQyT8C\&prin tsec $=$ frontcover $\& \mathrm{hl}=\mathrm{id} \# \mathrm{v}=$ one page\&q\&f=false, akses 13 Juni 2017

Julia, R. (2013). Hubungan Faktor Lingkungan dan Perilaku terhadap Kejadian Skabies di Pondok Pesantren Al Furqon Kecamatan Sidayu, Kabupaten Gresik Jawa Timur. Skripsi. Depok: Universitas Indonesia.

Pusat Pengembangan Penelitian dan Pendidikan Pelatihan Kementrian Agama. (2011). Analisis dan Interpretasi Data Pada Pondok Pesantren, Madrasah Diniyah (Madin), Taman Pendidikan Qur'an (TPQ) Tahun Pelajaran 20112012.

http://pendis.kemenag.go.id/fi le/dokumen/pontrenanalisis.p df. Diakses tanggal $20 \mathrm{Mei}$ 2018.

Wijayanti, K (2007). Peran POSKESTREN dalam Meningkatkan Kesehatan Remaja.

https://media.neliti.com/media /publications/21073-ID-peranpos-kesehatan-pesantrendalam-meningkatkankesehatan-reproduksiremaja.pdf akses Juni 2019. 